\title{
Key pasture and milksolids production indicators from two Waikato farmlets differing in inputs, stocking rate, pasture allowance and nitrate leaching
}

\author{
C.G. ROACH, C.B. GLASSEY and K.A. MACDONALD
}

DairyNZ, Private Bag 3221, Hamilton 3240, New Zealand

Chris.Roach@dairynz.co.nz

\begin{abstract}
Two DairyNZ farmlets, differing in nitrogen fertiliser inputs, cow genetic merit and autumn/winter grazing management, with stocking rates of 2.6 ('Future') and 3.2 ('Current') cows/ha, were compared for pasture residual and quality over 4 years. Target intakes for lactating cows were 18 and $16 \mathrm{~kg} \mathrm{DM} / \mathrm{cow} /$ day, respectively, with target grazing residuals of $3.5-4 \mathrm{~cm}$ $(1500 \mathrm{~kg} \mathrm{DM} / \mathrm{ha}$ in late winter/spring, 7-8 clicks on the rising plate meter) for both herds. Measurement of grazing residuals, pasture quality and botanical composition identified small differences between farmlets. Grazing residuals on the Future farmlet averaged $0.2 \mathrm{~cm}$ ( 0.4 clicks on rising plate meter, RPM) $(\mathrm{P}<0.01)$ higher than on the Current farmlet with the difference being $0.35 \mathrm{~cm}$ in late spring $(\mathrm{P}<0.01), 0.2$ $\mathrm{cm}$ in summer $(\mathrm{P}<0.05), 0.3 \mathrm{~cm}$ in autumn $(\mathrm{P}<0.05)$ and not significantly different in winter and early spring. The metabolisable energy (ME) content of the pasture on the Future farmlet was on average $0.2 \mathrm{MJ} \mathrm{ME} / \mathrm{kg}$ $\mathrm{DM}(\mathrm{P}=0.06)$ lower than the Current farmlet over the 4 years (11.6 and $11.8 \mathrm{MJ} \mathrm{ME} / \mathrm{kg} \mathrm{DM}$, respectively), with the difference being significant $(\mathrm{P}<0.05)$ in early spring. Despite lower annual pasture production, pasture allowance per cow was higher on the Future farmlet which resulted in higher pasture intakes and milksolids production per cow, though lower production per hectare. The results showed that grazing residuals and pasture quality did not decline markedly with increasing pasture allowance.
\end{abstract}

Keywords: pasture, grazing residual, pasture allowance, pasture quality, milksolids

\section{Introduction}

The New Zealand dairy industry is seeking farming systems that will reduce the loss of nitrates and other pollutants from the farm to naturally occuring waterways. The Pastoral 21 (P21) project, which this study was part of, tested strategies that have, through modelling, shown to be potentially useful for reducing nitrate leaching (Burggraaf et al. 2011; Beukes et al. 2011). These strategies include: reducing inputs of feed and nitrogen $(\mathrm{N})$ fertiliser; lowering stocking rate to match feed supply and reducing urine $\mathrm{N}$ deposition by the milking herd and all replacement animals (lower stocking rate equals lower replacement animal numbers); standing animals off pasture at times when the risk of $\mathrm{N}$ leaching from freshly deposited urine is greatest; using animals of high genetic merit (Breeding Worth, BW) that have the ability to produce more milk compared with cows of low genetic merit, and excrete less dietary $\mathrm{N}$ as faeces and urine (Woodward et al. 2011). Many of these strategies have implications for the management of key interactions between pastures and grazing animals that drive production efficiency and costs of production.

For a lower stocked system to achieve similar production per hectare, production per cow must be higher, which requires higher intakes $(\mathrm{kg} \mathrm{DM} / \mathrm{cow} /$ day). Baudracco et al. (2010) identified that achieving higher intakes required higher allowances and grazing residuals. However, higher grazing residuals can lead to decreased pasture quality at subsequent grazings (Lee et al. 2008), and this can reduce milksolids (MS) production (Hoogendoorn et al. 1988). Thus, the unanswered question is, will a well-managed new farm system with high pasture allowances have high grazing residuals and reduced pasture quality? The objective of the project was to determine, using farmlets, if the output of the model simulation could be demonstrated in practice. One farmlet (Current) used best practise decision rules to optimise profitability from Waikato pasture. A second farmlet (Future) tested strategies with the aims of reducing current $\mathrm{N}$ leaching of 40$60 \mathrm{~kg} \mathrm{~N} / \mathrm{ha} / \mathrm{yr}$ to $20-25 \mathrm{~kg} \mathrm{~N} / \mathrm{ha} / \mathrm{yr}$, while maintaining MS (milkfat and protein) production per hectare and profitability at the same level as the Current farmlet.

This paper investigates the consequences of lowering stocking rate, which is a component of a lower input approach to reducing nitrate leaching, on grazing residuals and pasture quality in the Future farmlet compared with those in the Current farmlet.

\section{Materials and methods}

The two farmlets (Table 1) were established at the DairyNZ Scott farm in June 2011 and were managed for 4 years until June 2015:

1) 'Future'. The farmlet set up was aimed at reducing nitrogen $(\mathrm{N})$ loss via animal cycling by using higher 
Breeding Worth (BW) cows (BW=170, May 2011) at a lower stocking rate (2.6 cows/ha), lower $\mathrm{N}$ usage $(50 \mathrm{~kg} \mathrm{~N} / \mathrm{ha} / \mathrm{yr})$ and standing cows off on a wood chip pad during critical $\mathrm{N}$ excretion and leaching periods (Shepherd et al. 2011).

2) 'Current'. The farmlet representing a system aimed at high production and profitability, with higher rates of $\mathrm{N}$ fertiliser (150 kg N/ha/yr), a higher stocking rate (3.2 cows/ha), and some imported feed, if required. The cows were also lower $\mathrm{BW}(\mathrm{BW}=90$, May 2011) than the Future cows.

Both farmlets consisted of 26, 0.5 ha paddocks. Five paddocks in each farmlet were sown in tall fescue and white clover in 2008, the remainder in perennial ryegrass and white clover (sown 2001-2011). Two paddocks on each farmlet were sprayed out and resown each autumn with perennial ryegrass and white clover. The paddocks were paired between the farmlets and on five different soil types. Soil type was used for blocking for statistical analysis. MS production was calculated from daily records of milk yield and weekly herd tests for fat and protein content.

\section{Pasture assessment and allocation}

One day each week, pasture cover on every paddock was visually scored by experienced assessors and calibrated with quadrat cuts, to estimate pasture mass (Jensen et al. 2005). On each occasion, ten $0.2 \mathrm{~m}^{2}$ quadrats (4 post-grazing, 6 pre-grazing) were visually assessed, cut to ground level, and the herbage washed, then dried for at least 48 hours at $95^{\circ} \mathrm{C}$. Visual scores were plotted against measured dry matter as a scatter plot in Microsoft Excel and a linear trend-line generated. The equation for the trend-line was then applied to the visual assessments of pasture cover for that week. The adjusted covers were used for calculating pasture growth. The average $\mathrm{R}^{2}$ from the 203 sets of cuts was 0.90 , average slope was 1.15 and average intercept was $-317 \mathrm{~kg} \mathrm{DM} / \mathrm{ha}$. After each weekly assessment the paddock covers were entered into a spreadsheet and a feed wedge (DairyNZ 2010) generated for each farmlet. The management team then made the grazing decisions for the next week for each farmlet.

Table 1 Description of Pastoral 21 (P21) Waikato farmlets on DairyNZ's Scott Farm.

\begin{tabular}{lcc}
\hline Farmlet & Current & Future \\
\hline Size (ha) & 13 & 13 \\
Cows per farmlet & 42 & 34 \\
Cows/ha & 3.2 & 2.6 \\
Liveweight/ha (kg) & 1650 & 1335 \\
Predicted N leaching (kg/ha/yr) & $40-60$ & $20-25$ \\
\hline
\end{tabular}

Pasture growth was calculated from the change in calibrated pasture cover of paddocks that had not been grazed or harvested since the previous weekly assessment. These were used to calculate monthly and annual pasture growth data for each farmlet.

On 3 days each week pre- and post-grazing covers for both herds were assessed visually. These assessments were calibrated against the weekly quadrat cuts and used to calculate apparent pasture intakes. Estimates of annual pasture intake were calculated by using the average of the 3 measurement days as an estimated daily intake for that week, and summing all weeks. Preand post-grazing rising plate meter (RPM) heights were also recorded. The data reported here are expressed as RPM height, as this is the common term used by farmers.

For the majority of lactation, target intakes (from the pre-experimental modelling) were $18 \mathrm{~kg} \mathrm{DM} /$ cow/ day for the Future herd and $16 \mathrm{~kg} \mathrm{DM} / \mathrm{cow} /$ day for the Current herd, above a target grazing residual of 7-8 clicks on the RPM for both herds (approximately 1500 $\mathrm{kg} \mathrm{DM} / \mathrm{ha}$ ). The target pre-grazing pasture cover was calculated by multiplying the target intake by the herd size, dividing by the daily break size, then adding the target residual, e.g. (18 kg DM/cow x 34 cows $) / 0.5$ ha/ day $=1224+1500$ residual $=2724 \mathrm{~kg} \mathrm{DM} / \mathrm{ha}$. Pasture and cow management decision rules were similar to those of Macdonald \& Penno (1998). Paddocks with covers above the target pre-grazing cover were closed for silage, and supplements were fed if pre-grazing covers were below the target. Rotation length (area grazed/day) was similar for both herds, apart from early spring when the Future herd had a slightly faster rotation (larger area/day). There was little topping of pastures post-grazing $(<3$ paddocks on each farmlet per year).

Pasture samples were hand-clipped (once per week between 8:30 and 10:30 am) from the next paddock to be grazed by each farmlet herd to the approximate grazing height, using hand shears. Subsamples of the pasture were oven-dried on the day of collection at $60^{\circ} \mathrm{C}$ for at least 48 hours, ground and analysed by near infrared reflectance spectroscopy (Corson et al. 1999) for: acid detergent fibre (ADF), ash, crude protein, dietary anion-cation difference (DCAD), lignin, lipids, metabolisable energy (ME, calculated from organic matter digestibility (OMD)), neutral detergent fibre (NDF), OMD and soluble sugars and starches (SSS). In 2 weeks of each month further subsamples were taken and dissected into perennial ryegrass, tall fescue, other grasses, white clover, other legumes, herbs, weeds, and dead matter, before drying at $95^{\circ} \mathrm{C}$ for at least 48 hours to determine botanical composition on a dry weight basis. 


\section{Analysis of data}

A mixed models approach to a split-plot analysis of variance (Proc Mixed, SAS 9.3) was used to analyse the pasture data. Analyses were performed separately for four seasons and across the whole year. Winter was defined as June and July; Early Spring as August and September; Late Spring as October and November; Summer as December, January and February; and Autumn as March, April, and May. The model included Species (ryegrass, tall fescue), Farmlet, Year, and Farmlet-by-Year interaction as fixed effects and block and block-by-Farmlet interaction as random effects. None of the Farmlet by year interactions were significant and only Farmlet main effects across species and years are reported. Paddocks were used as replicates. Significance is declared if $\mathrm{P}<0.05$ and results are presented as least-squares means standard errors of the difference.

\section{Results}

A small increase in grazing residual was measured on the Future farmlet compared with the Current farmlet despite the target residuals being similar for both herds. Grazing residuals on average were 0.4 RPM clicks $(0.2$ $\mathrm{cm})$ higher $(\mathrm{P}<0.01)$ for the milking cows over the 4 years (Table 2), which equates to $60-90 \mathrm{~kg} \mathrm{DM} / \mathrm{ha}$ (L'Huillier \& Thomson 1988). There was no difference in winter residuals, while on the Future farmlet there was a trend for higher residuals in early spring, and significantly higher residuals in late spring, summer, and autumn.

Recommended target grazing residuals for milking cows to maximise pasture regrowth and quality are 7 to 9 clicks on the RPM (Chapman et al. 2014). The Future herd's average residual exceeded 9 clicks in late spring and this was also when the largest seasonal difference in residuals $(0.7$ RPM clicks, $\mathrm{P}<0.01)$ between the farmlets was measured (Table 2).

Pasture on the Future farmlet was on average 0.2 MJ

Table 2 Grazing residuals (RPM clicks ${ }^{1}$ ) for milking cows on P21 Waikato farmlets at DairyNZ's Scott Farm. Average of 4 years data ( $1^{\text {st }}$ June 2011 to $30^{\text {th }}$ May 2015).

\begin{tabular}{lcccc}
\hline Farmlet & Current & Future & SED & P value \\
\hline Whole year & 7.8 & 8.2 & 0.12 & $* *$ \\
Winter & 7.6 & 7.7 & 0.29 & NS \\
Early spring & 7.4 & 7.7 & 0.14 & + \\
Late spring & 8.4 & 9.1 & 0.20 & $*$ \\
Summer & 8.1 & 8.5 & 0.14 & $*$ \\
Autumn & 7.0 & 7.5 & 0.22 & $*$ \\
\hline
\end{tabular}

${ }^{1}$ A RPM click is $0.5 \mathrm{~cm}$ compressed height. NS = not significant, $+=\mathrm{P}<0.1,{ }^{*}=\mathrm{P}<0.05,{ }^{* *}=\mathrm{P}<0.01$
$\mathrm{ME} / \mathrm{kg}$ DM lower than the Current pasture $(\mathrm{P}=0.058)$, with the difference being significant only in early spring (Table 3). As ME was calculated from OMD, it showed the same pattern as ME - a trend to be lower overall, and significantly lower in early spring (data not presented).

Pasture crude protein content was lower on the Future farmlet in early spring and overall (Table 4). ADF, NDF, lipids and SSS showed no differences between farmlets. There were significant year effects, but no year-treatment interactions.

Comparing the ryegrass pastures, the Future pastures had a higher white clover content than the Current pastures $(\mathrm{P}<0.05)($ Table 5). There were no other differences in botanical composition. The small number of tall fescue paddocks meant not all seasons had tall fescue botanical samples from both farmlets, so results are not reported. There were some effects of year on botanical composition (mainly in autumn) but no interactions between year and treatment.

More pasture was grown per hectare on the Current farmlet than the Future farmlet (Table 6), at least partly due to the higher nitrogen fertiliser use on the Current farmlet, however, the pasture grown per cow was higher

Table 3 Pasture metabolisable energy (MJ ME/kg DM) on P21 Waikato farmlets at DairyNZ's Scott Farm. Average of 4 years data ( $1^{\text {st }}$ June 2011 to $30^{\text {th }}$ May 2015).

\begin{tabular}{lcccc}
\hline Farmlet & Current & Future & SED & P value \\
\hline Whole Year & 11.8 & 11.6 & 0.11 & + \\
Winter & 12.2 & 12.0 & 0.11 & NS \\
Early spring & 12.7 & 12.5 & 0.08 & * \\
Late Spring & 12.3 & 12.3 & 0.11 & NS \\
Summer & 11.2 & 11.0 & 0.23 & NS \\
Autumn & 11.8 & 11.6 & 0.24 & NS \\
\hline
\end{tabular}

NS $=$ not significant $,+=P<0.1,{ }^{*}=P<0.05$

Table 4 Pasture crude protein (g/100g DM) on P21 Waikato farmlets at DairyNZ's Scott Farm. Average of 4 years data ( $1^{\text {st }}$ June 2011 to $30^{\text {th }}$ May 2015).

\begin{tabular}{lcccc}
\hline Farmlet & Current & Future & SED & P value \\
\hline Whole Year & 21.1 & 20.2 & 0.35 & * \\
Winter & 20.9 & 20.1 & 0.47 & NS \\
Early spring & 23.4 & 21.8 & 0.65 & * \\
Late Spring & 21.3 & 20.5 & 0.79 & NS \\
Summer & 19.3 & 18.7 & 0.74 & NS \\
Autumn & 21.4 & 20.6 & 0.82 & NS \\
\hline
\end{tabular}

NS $=$ not significant, ${ }^{*}=\mathrm{P}<0.05$ 
on the Future farmlet as a result of fewer cows per hectare. Pasture utilisation (pasture eaten/pasture grown, expressed as a percentage) was $84 \%$ for both farmlets. Estimated pasture intakes, through visual estimates of pasture disappearance, indicated the Future cows ate approximately $0.5 \mathrm{t} \mathrm{DM} / \mathrm{cow}$ more than the Current cows, and produced $75 \mathrm{~kg} \mathrm{MS} / \mathrm{cow}$ more (Table 6). The Current herd produced on average $29 \mathrm{~kg}$ more MS/ha/ year than the Future herd. Pasture disappearance from September to December (when pasture supply is less likely to be limiting) suggested the Current herd were eating $16 \mathrm{~kg} \mathrm{DM} / \mathrm{cow} /$ day (their target intake) while the Future cows were eating $17.4 \mathrm{~kg} \mathrm{DM} / \mathrm{cow} /$ day (target intake of $18 \mathrm{~kg} \mathrm{DM} /$ cow/day) (Table 6).

\section{Discussion}

Target daily intakes for milking cows were $18 \mathrm{~kg} \mathrm{DM} /$ cow for the Future herd and $16 \mathrm{~kg} \mathrm{DM} /$ cow for the Current cows, and the higher residuals on the Future farmlet suggested the herd was unable to attain its target intake. This was supported by the pre- and post-grazing measurements of pasture disappearance as the Future herd's estimated intake from September to December (when pasture supply is least likely to be limiting) was only $1.4 \mathrm{~kg} \mathrm{DM} / \mathrm{cow} /$ day higher than the Current herd (Table 6), which is less than the target intake difference of $2 \mathrm{~kg} \mathrm{DM} / \mathrm{cow} /$ day. This inability to reach target intake could have been due to the target residual restricting intake for the Future herd, or the target intake being too high. Previous research has identified that to achieve an increase in pasture intake, pasture allowance ( $\mathrm{kg} \mathrm{DM} /$ cow to ground level) should be increased by a larger amount. The equation derived in the review by Baudracco et al. (2010) calculates that to increase intakes from 16 to $18 \mathrm{~kg} \mathrm{DM} / \mathrm{cow} /$ day requires pasture allowance to be increased by $16 \mathrm{~kg} \mathrm{DM} /$ cow/day. Pasture allocation for the farmlets typically provided pasture allowances of $40 \mathrm{~kg} \mathrm{DM} / \mathrm{cow} /$ day (measured to ground level) for the Future herd and $34 \mathrm{~kg} \mathrm{DM} / \mathrm{cow}$ day for the Current herd, a $6 \mathrm{~kg} \mathrm{DM} / \mathrm{cow} /$ day difference

Table 5

Pasture white clover content (\% DM) on P21 Waikato farmlets at DairyNZ's Scott Farm. Average of 4 years data ( $1^{\text {st }}$ June 2011 to $30^{\text {th }}$ May 2015).

\begin{tabular}{lcccc}
\hline Farmlet & Current & Future & SED & P value \\
\hline Whole Year & 8.1 & 10.9 & 1.23 & $*$ \\
Winter & 4.1 & 3.5 & 1.32 & $\mathrm{NS}$ \\
Early spring & 6.0 & 10.6 & 2.05 & $\mathrm{NS}$ \\
Late Spring & 5.8 & 10.4 & 2.33 & + \\
Summer & 12.6 & 18.7 & 3.50 & $\mathrm{NS}$ \\
Autumn & 10.5 & 11.26 & 1.90 & $\mathrm{NS}$ \\
\hline
\end{tabular}

NS $=$ not significant, $+=P<0.1,{ }^{*}=P<0.05$ between the two groups, well below the $16 \mathrm{~kg} \mathrm{DM}$ estimate of Baudracco's equation. Using the allowances above, Baudracco's equation gives calculated daily intakes of $15.6 \mathrm{~kg} \mathrm{DM} / \mathrm{cow}$ for the Future herd $(2.4 \mathrm{~kg}$ below target) and $14.5 \mathrm{~kg} \mathrm{DM} / \mathrm{cow}$ for the Current herd (1.5 kg below target), a difference of $1.1 \mathrm{~kg} \mathrm{DM} / \mathrm{cow} /$ day, implying that higher residuals would be expected for the Future herd (and above-target residuals for both herds). The higher BW of the cows in the Future cows may have given them more drive to eat (appetite) than the Current cows (Rossi et al. 2005), allowing them to achieve lower residuals than would otherwise occur.

There were small differences in pasture quality, with the Future pasture being lower in crude protein and OMD (and therefore ME). This difference in quality cannot be directly attributed to the increased grazing residuals on the Future farmlet, as other management differences between the two systems (e.g. $\mathrm{N}$ use, autumn/winter standoff) also contributed. There being no significant difference in quality during or following the seasons with the largest differences in residuals (late spring, summer and autumn), suggests a lack of a cause and effect relationship. The size of the differences may have been reduced by the higher white clover content of the Future pastures due to white clover generally having higher protein and digestibility than perennial ryegrass. It should also be noted that the pasture quality results are estimates by NIRS, not direct measurements.

Compared with the Current herd the Future herd was offered an additional $670 \mathrm{~kg} \mathrm{DM} / \mathrm{cow} / \mathrm{yr}$ and an additional $550 \mathrm{~kg} \mathrm{DM} / \mathrm{cow}$ disappeared (apparently eaten). The average cow in the Future herd apparently consumed $57420 \mathrm{MJ}$ ME (4950 kg DM x 11.6 MJ $\mathrm{ME}$ ), $5500 \mathrm{MJ} \mathrm{ME} / \mathrm{year}$ more than the average cow in the Current herd, after allowing for the small measured drop in pasture ME from 11.8 to $11.6 \mathrm{MJ} \mathrm{ME} / \mathrm{kg}$ DM. Assuming that this energy was available for MS

Table 6 Annual pasture growth and pasture allowance, pasture disappearance (September-December) and $\mathrm{MS}^{1}$ yield for Pastoral 21 (P21) Waikato farmlets on DairyNZ's Scott Farm. Average of 4 years data ( $1^{\text {st }}$ June 2011 to $30^{\text {th }}$ May 2015).

\begin{tabular}{lcc}
\hline Farmlet & Current & Future \\
\hline Pasture grown (t DM/ha/yr) & 16.9 & 15.4 \\
Pasture grown per cow (t DM/cow/yr) & 5.23 & 5.90 \\
Annual pasture disappearance (t DM/cow/yr) & 4.40 & 4.95 \\
Average pasture disappearance & & \\
September-December (kg DM/cow/day) & 16.0 & 17.4 \\
MS (kg/cow/yr) & 369 & 444 \\
MS (kg/ha/yr) & 1193 & 1164 \\
\hline
\end{tabular}

${ }^{1} \mathrm{MS}=$ milkfat and protein 
production at $77 \mathrm{MJ} \mathrm{ME} / \mathrm{kg} \mathrm{MS}$, (Nicol \& Brookes 2007), then the Future herd would be expected to produce an additional $71 \mathrm{~kg} \mathrm{MS} / \mathrm{cow}$ which is close to the $75 \mathrm{~kg} \mathrm{MS} / \mathrm{cow}$ measured (Table 6).

\section{Conclusions}

In this project, a higher pasture allowance in a farmlet with $9 \%$ lower pasture growth and $19 \%$ fewer cows did not result in large differences in grazing residuals. The cows on the Future farmlet grazed to within 0.2 $\mathrm{cm}$ of the residual achieved by the Current cows. Although this difference was statistically significant, and potentially contributes to lost milk production for the Future herd, the difference was small and did not result in a large decrease in pasture quality, and therefore would not be expected to have a large effect on MS production. This demonstrates that systems with high pasture allowances and higher targeted intakes can maintain pasture quality, but rely on having a set of decision management rules and frequent monitoring so that desired post-grazing residuals are maintained.

\section{ACKNOWLEDGEMENTS}

This work was conducted through the Pastoral 21 Environment Programme (C10X1117), jointly funded by MBIE, DairyNZ, Fonterra and Beef + Lamb New Zealand. The authors wish to acknowledge the other members of the DairyNZ Scott farm walk team for allowing their management to be critiqued, the DairyNZ technical team for assistance, and Barbara Kuhn-Sherlock for statistical analysis.

\section{REFERENCES}

Baudracco, J.; Lopez-Villalobos, N.; Holmes, C.W.; Macdonald, K.A. 2010. Effects of stocking rate, supplementation, genotype and their interactions on grazing dairy systems: a review. New Zealand Journal of Agricultural Research 53: 109-133.

Beukes, P.C.; Romera, A.J.; Gregorini, P.; Clark, D.A.; Chapman, D.F. 2011. Using a whole-farm model linked to the APSIM suite to predict production, profit and $\mathrm{N}$ leaching for next generation dairy systems in the Canterbury region of New Zealand. 19 $9^{\text {th }}$ International Congress on Modelling and Simulation. Perth, Australia. pp. 760-766. http://mssanz.org.au/modsim2011

Burggraaf, V.; Vogeler, I.; Beukes, P.; Clark, D. 2011. Performance of an efficient dairy farm system using combined environmental impact mitigation strategies in a variable climate. In Proceedings of the 5th World Congress of Conservation Agriculture incorporating the 3rd Farming Systems Design Conference, September 2011, Brisbane, Australia. www.wcca2011.org

Chapman, D.; McCarthy, S.; Kay, J. 2014. Hidden dollars in grazing management: Getting the most profit from your pastures. pp. 21-36. In: Proceedings of the South
Island Dairy Event. SIDE Secretariat, Conference and Professional Development, Lincoln University.

Corson, D.C.; Waghorn, G.C.; Ulyatt, M.J.; Lee, J. 1999. NIRS: Forage analysis and livestock feeding. Proceedings of the New Zealand Grassland Association 61: 127-132.

DairyNZ 2010. Farmfact 1-14. Feed wedges. Accessed 06/06/2012. http://www.dairynz.co.nz/file/fileid/36306

Hoogendoorn C.J.; Holmes, C.W.; Chu, A.C.P. 1988. Grazing management in spring and subsequent dairy cow performance. Proceedings of the New Zealand Grassland Association 49: 7-10.

Jensen, R.N.; Clark, D.A.; Macdonald, K.A. 2005. Resource efficient dairying trial: measurement criteria for farm systems over a range of resource use. Proceedings of the New Zealand Grassland Association 67: 47-52.

Lee, J.M.; Donaghy D.J.; Roche, J.R. 2008. Effect of defoliation severity on regrowth and nutritive value of perennial ryegrass (Lolium perenne L.) dominant swards. Agronomy Journal 100: 308-314.

L'Huillier, P.J.; Thomson, N.A. 1988. Estimation of herbage mass in ryegrass-white clover dairy pastures. Proceedings of the New Zealand Grassland Association 49: 117-122.

Macdonald, K.A.; Penno, J.W. 1998. Management decision rules to optimise milksolids production on dairy farms. Proceedings of the New Zealand Society of Animal Production 58: 132-135.

Nicol, A.M.; Brookes, I.M. 2007: The metabolisable energy requirements of grazing livestock. pp. 151172. In: Pasture and supplements for grazing animals. Eds. Rattray, P.V.; Brookes, I.M.; Nicol, A.M. New Zealand Society of Animal Production, Occasional Publication No 14.

SAS Institute 2010. Statistical analysis software, version 9.3. SAS Institute Inc., Cary, NC, USA.

Rossi, J.L.; Macdonald, K.A.; Thorrold, B.S.; Hodgson, J.; Holmes, C.W. 2005. Differences in grazing behaviour and herbage intake between genotypes of Holstein-Friesian dairy cows grazing short or long swards. Proceedings of the New Zealand Society of Animal Production 65: 236-240.

Shepherd, M.; Phillips, P.; Snow, V. 2011. The challenge of late summer urine patches in the Waikato region. In: Adding to the knowledge base for the nutrient manager. Eds. Currie, L.D.; Christensen, C.L. Occasional Report No. 24. Fertilizer and Lime Research Centre, Massey University, Palmerston North, New Zealand. 8 pp. http://flrc.massey.ac.nz/publications.html

Woodward, S.L.; Waghorn, G.C.; Bryant, M.A.; Mandok, K. 2011. Are high breeding worth index cows more feed conversion efficient and nitrogen use efficient? Proceedings of the New Zealand Society of Animal Production 71: 109-113. 
